\title{
Developing Accuracy and Fluency in Spoken English of Chinese EFL Learners
}

\author{
Zhiqin Wang ${ }^{1}$ \\ ${ }^{1}$ School of Foreign Languages, China West Normal University, China \\ Correspondence: Zhiqin Wang, School of Foreign Languages, China West Normal University, No. 1 Shi Da \\ Road, Nanchong 637009, Sichuan, China. Tel: 86-180-3047-2313. E-mail: wzq76@163.com
}

Received: November 4, 2013 Accepted: December 7, 2013 Online Published: January 6, 2014

doi:10.5539/elt.v7n2p110 URL: http://dx.doi.org/10.5539/elt.v7n2p110

The research is financed by Department of Education of Sichuan Province (Project No. 12SA135), Sichuan Center for Education Development Research (Project No. CJF012013), Nanchong City Federation of Social Sciences in Sichuan Province, and the Center for Translation and Research of Chinese Culture and Literature.

\begin{abstract}
Chinese EFL learners may have difficulty in speaking fluent and accurate English, for their speaking competence are likely to be influenced by cognitive, linguistic and affective factors. With the aim to enhance those learners' oral proficiency, this paper first discusses three effective models of teaching English speaking, and then proposes a four-step pedagogical method in which activities are carried out through four stages: Pre-speaking, while-speaking, post-speaking and extension practice.
\end{abstract}

Keywords: speaking accuracy and fluency, Chinese EFL learners, three models of teaching English speaking, a suggested four-step pedagogical method

\section{Introduction}

English speaking is greatly ignored in Chinese EFL classrooms, for most teachers tend to talk a lot in class, while giving few chances for students to speak English. Consequently, those learners are underdeveloped in their spoken English. Speaking competence mainly covers speaking accuracy and fluency. Speaking accuracy indicates "the extent to which the language produced conforms to target language norms" (Yuan \& Ellis, 2003, p. 2 ), which involves the correct use of pronunciation, vocabulary and grammar. Speaking fluency refers to the ability to produce the spoken language "without undue pausing or hesitation" (Skehan, 1996, p. 22). Too many hesitations and pauses in speaking may obstruct the speaking fluency and also depress the speaker.

As an essential tool for language teaching and learning, speaking can "facilitate language acquisition and development" (Goh, 2007, p. 1), and it can be beneficial to learners' academic achievement as well as professional success (Saunders \& O'Brien, 2006). As an important aspect of language skills, English speaking should not be devalued but be "developed in its own right" (Goh, 2005, p. 105). Therefore, good speaking competence is essential to English learners, especially for those English majors at normal universities, for English teaching is likely to be their lifelong career.

With the aim to improve Chinese EFL learners' speaking competence, this paper first explores three factors affecting students' speaking competence, then elaborates three effective models of teaching English speaking, and finally puts forward a four-step pedagogical method in which activities can be carried out stage by stage: Pre-speaking, while-speaking, post-speaking and extension practice.

\section{Factors Influencing Learners' Speaking Competence}

Speaking occurs spontaneously and transiently in real time, so producing spoken language can be very time-constraint (Wang, 2007). Influenced by cognitive factors, linguistic factors and affective factors, it is really challenging for Chinese EFL learners to speak English fluently and accurately.

\subsection{Cognitive Factors}

According to Levelt (1989), the speaking processes include conceptualization, formulation and articulation. Conceptualization deals with what information can be chosen to express the meaning. Formulation requires the 
speaker to find out what proper words to use in appropriate grammatical structure. And articulation needs the speaker to produce the speech with his articulatory organs. As all the three processes take place on the spur of the time, it is quite possible for learners to make mistakes in face-to-face communication. Therefore their speaking may be filled with "hesitations, false-starts, grammatical inaccuracies and limited vocabulary" (Hughes, 2002, p. 77). In this sense, both their speaking fluency and accuracy may be affected.

Besides, human's mind is a "limited-capacity processor" (McLaughlin \& Heredia, 1996, p. 214), so it is not easy to focus on everything at the same time. Because of the limited attentional capacity, focusing on one area reduces students' attention to other areas. Over-focus on accuracy may result in the lack of fluency, and too much emphasis on fluency may lead to the lack of accuracy (Skehan \& Foster, 1999). Therefore, it is necessary for Chinese EFL learners to keep a balance between speaking accuracy and fluency.

\subsection{Linguistic Factors}

The correct use of language forms is critical for learners' oral proficiency (Saunders \& O'Brien, 2006). Comparing with native speakers, it is harder for EFL learners to use the accurate pronunciation, grammar and vocabulary (Bygate, 2005).

Pronunciation plays an important role in intelligibility (Goh, 2007). Mispronouncing a single sound causes the listener's misunderstanding, and various uses of stresses as well as intonations result in totally different meanings. In addition, Chinese and English differ a lot in sounding systems, so those pronunciations which do not exist in Chinese cause great difficulty for Chinese EFL learners. If learners often make mistakes in sounds, stress and intonation, their speaking accuracy is greatly affected.

Besides, grammar plays a key role in learning the structure of English. But learning the accurate use of grammar is one thing, correctly using it in one's speech is another. Some students are good at grammar in reading and writing; but they may often make mistakes in their spoken English. It is rather difficult for EFL learners to transfer the correct grammar to their speaking (Larsen-Freeman, 2001), so Chinese EFL learners should be facilitated in their grammar so that they can make progress in their speaking accuracy.

Vocabulary is also important for EFL learners, just as the significance of bricks to a building. If the receptive vocabulary is rather limited, learners can hardly put the "receptive vocabulary knowledge into productive use" (Nation, 2001, p. 129), so it is essential for Chinese EFL students to store a wealth of vocabulary in their long-term memory. In addition, the ability to quickly recall words from one's mind may affect the speaking fluency (Levelt, 1989; Carter, 2001). Hence Chinese EFL learners should be able to have a fast access to the words and expressions in their mind while speaking so that their speaking fluency can be enhanced.

\subsection{Affective Factors}

Apart from cognitive and linguistics factors, learners' speaking competence is influenced by affective factors. Both anxiety and self restriction have an impact on learners' oral proficiency.

Anxiety is the affective factor that "most pervasively obstructs the learning process" (Arnold \& Brown, 1999, p. 8). Worrying about being "wrong, stupid, or incomprehensible" (Brown, 2001, p. 269) greatly affects learners' speaking performance. Numerous of Chinese EFL students are rather nervous in class (Liu, 2006), especially when they are asked to speak in class without any preparation. Too much nervousness makes learners "tongue-tied or lost for words" (Shumin, 2002, p. 206) and absolutely influences their achievement in foreign language classroom (Zhang \& Jia, 2006). Therefore, Chinese EFL learners should be supported enough before speaking, so that they can lessen their anxiety and perform better in speaking.

Restricted by the face-saving culture in China, many learners are not brave enough to talk English in classroom. Bearing in mind that "speech is silver, silence is gold", many students choose to keep silent so as to avoid losing face in public. Affected by such self-restriction, it becomes harder and harder for them to open their mouth as time goes by. Since risk taking is viewed as an essence for "successful learning of a second language" (Brown, 2007, p. 160), Chinese EFL learners should be motivated to speak bravely in order to promote their speaking competence gradually.

\section{Methodology}

\subsection{Participants}

100 junior English majors at China West Normal University (CWNU), Sichuan, China take part in the survey. Most of them are girls and a few are boys, who are around 20 years old. The majority of those participants come from the countryside, who are not well developed in their spoken English as their peers in big cities. In order to pass the entrance examination, they have focused too much on their reading and writing skills instead of 
developing their speaking competence.

In the second year of university study, all of them need to participate in the TEM-4 (Test for English Majors), a gatekeeper for their future job-hunting. Under the pressure of such a crucial exam which emphasizes the skills of listening, reading and writing, those participants' speaking competence is thus underestimated. As most of them will become English teachers after graduation, good speaking competence is undoubtedly essential to those participants.

\subsection{Data Collection}

Aiming to find out what problems exist in the speaking competence of those English majors at CWNU, a survey of questionnaire is employed in this project. The sample questionnaire (see Appendix 1) is composed of 10 close-ended questions. Question 1 and 2 mainly investigate their speaking accuracy. Question 3, 4 and 8 chiefly examine their speaking fluency.

100 questionnaires are randomly distributed to those participants, who are given clear instructions on how to complete the questionnaires before they start. They are required to choose one of the frequent adverbs of Seldom, Sometimes, and Often to fill in each blank according to their first reaction. All the questionnaires are finished in captive groups and are collected orderly and successfully.

\subsection{Data Analysis}

The data is given a descriptive statistics analysis. First of all, all the answers are put into the Excel Form. Next, the frequency of the answers is counted. And then, the percentage of those participants' speaking problem is figured out (see Appendix 2).

Table 1. Underdevelopment of speaking competence among junior English majors at CWNU

\begin{tabular}{lcccc}
\hline & \multicolumn{2}{l}{ Speaking accuracy } & \multicolumn{2}{c}{ Speaking fluency } \\
\cline { 2 - 5 } & $\begin{array}{c}\text { Make grammar } \\
\text { mistakes }\end{array}$ & Mispronounce & Hesitate and pause & $\begin{array}{c}\text { Forget } \\
\text { vocabulary }\end{array}$ \\
\hline Often & $20 \%$ & $46 \%$ & $44 \%$ & $45 \%$ \\
Sometimes & $64 \%$ & $45 \%$ & $50 \%$ & $51 \%$ \\
Seldom & $16 \%$ & $9 \%$ & $6 \%$ & $4 \%$ \\
\hline
\end{tabular}

From the above table, it can be seen that the speaking competence of those junior English majors at CWNU is underdeveloped. As for the speaking accuracy, $46 \%$ students often make mistakes in grammar and $20 \%$ have errors in pronunciation. Mispronouncing and using wrong grammar in oral English definitely affect learners' speaking accuracy. As to the speaking fluency, $44 \%$ learners often pause and hesitate in their speech, and $45 \%$ frequently forget what vocabulary to use when speaking. Hesitating and pausing are likely to lose the listeners' interest, and failing to recall words from one's memory break down the conversation and thus hinder the smoothness of speaking.

\section{Three Models of Teaching Speaking}

Affected by the cognitive, linguistic and affective factors, it is rather demanding for those English majors to speak English both accurately and fluently. Therefore, teachers need to find efficient ways to help English learners to improve their speaking competence.

\subsection{Willis' Three-Stage Model}

Willis (1996) suggests three steps in teaching speaking: an input stage, a rehearsal stage and a performance stage. (1) In the input stage, students are given a good model to imitate; (2) In the rehearsal stage, learners implement the task within group members; (3) In the performance stage, students carry out the task before class.

This three-stage model is useful to enhance learners' oral proficiency. First of all, following a model can support learners with a good example of pronunciation, grammar and vocabulary. Furthermore, carrying out the task in small groups reduces learners' stress and increases everybody's chances to speak English. At last, performing the task before class motivates students to participate in class actively. By means of this three-stage model, learners are expected to improve their spoken English. 


\subsection{Florez's Five-Stage Model}

Florez (1999, p. 17) puts forward five stages in a speaking class: "preparation, presentation, practice, evaluation, and extension". (1) In the preparation stage, learners brainstorm about the topic. (2) In the presentation stage, learners are provided with a model to follow suit. (3) In the practice stage, learners produce the talk in small group. (4) In the evaluation stage, learners compare their output with a teacher-prepared speech. (5) In the extension stage, learners record an authentic conversation in their social context and report their findings to the class.

This model is also helpful to improve learners' speaking competence. Firstly, brainstorming about the topic supports learners with relevant background information, so that they have more to say in speaking. Secondly, a good model provides learners with sufficient language input in terms of pronunciation, vocabulary and grammar. Thirdly, talking in small group lessens learners' anxiety and increases their speaking time. Fourthly, comparing different uses of language helps learners to notice the correct language form, which may enhance their speaking accuracy. Lastly, recording an authentic conversation extends the oral task from class to real life, and sharing findings in class motivates students to finish the task more actively.

\subsection{Goh's Four-Stage Model}

Goh (2007) proposes a four-stage model of extending fluency tasks to focus on accuracy: (1) pre-speaking support: learners are helped with vocabulary and knowledge before speaking; (2) meaning-oriented speaking activity: learners' fluency is mainly developed; (3) language-focused activity: learners raise their awareness of the accurate use of the language; and (4) further practice: by means of task repetition, learners can develop a fluent and accurate speech.

This four-stage model is valuable to enhance learners' oral English competence. To begin with, through the support of language and knowledge prior to speaking, learners reduce their cognitive load and ease their anxiety. Furthermore, conducting the meaning-oriented activity first helps learners to focus on expressing their ideas efficiently so as to develop their speaking fluency. What's more, the language-focused activity is essential for learners to improve their speaking accuracy. Moreover, the further practice helps learners gradually to achieve a fluent and accurate speech by repeating the same task.

\section{A Suggested Four-Step Pedagogical Method for Chinese EFL Learners}

It can be seen that the above three models view speaking as a process: pre-speaking, while-speaking and post-speaking. However, their target learners are mainly those in ENL or ESL countries. Since English is spoken as a foreign language in China, it is more difficult for Chinese learners to speak accurate and fluent English. In order to develop Chinese EFL learners' speaking competence, this paper puts forward a four-step pedagogical method, in which activities are carried out through four stages: Pre-speaking; while-speaking; post-speaking; and extension practice.

\subsection{Pre-Speaking Activities}

Pre-task activities give learners enough time to plan and offer them some support in language as well as knowledge (Skehan, 1996), so the following activities can be conducted before learners' speaking: (1) pre-task planning, (2) pre-speaking support, and (3) authentic input.

Firstly, pre-task planning can lead to greater accuracy (Skehan \& Foster, 1999) and increased fluency (Yuan \& Ellis, 2003). Without any preparation before speaking, learners find it very challenging to handle all the speaking processes of conceptualization, formulation and articulation simultaneously. Therefore, learners should be given enough time to plan what to say and how to say it before speaking.

Secondly, pre-speaking support is vital to ease learners' anxiety, which can help learners in language, knowledge and strategy (Goh, 2007). Some related vocabulary and background information enable learners to generate more ideas in speaking; and certain speaking strategies help learners to deal with some possible breakdown in conversation. With such a "supportive and constructive classroom environment" (Horwitz, 2001, p. 119), Chinese EFL learners feel more comfortable in class and perform better in English speaking.

Thirdly, authentic input arouses learners' incentive to speak English. Lack of motivation may be the biggest challenge in the EFL classroom, so learners can be exposed to enough "authentic scenes, situations, and accents as well as voices" (Shumin, 2002, p. 209). For example, some DVD feature films can be used in the EFL classroom, which engage learners' enthusiasm and offer them an example as well as a prompt. Being exposed to the authentic input from visual and auditory channels (King, 2002), learners easily transfer "from comprehension (input) to expression (output)" (Tschirner, 2001, p. 312). Therefore, with some authentic and interesting 
materials, learners can be highly motivated to speak.

\subsection{While-Speaking Activities}

Due to the limited attentional capacity, it is not realistic to focus on speaking fluency and accuracy meanwhile. Therefore, the meaning can be mainly focused on during the task, and the language form may be emphasized afterwards (Willis, 2005). To develop the speaking fluency, some activities can be employed: (1) speaking tasks, (2) using a fluency technique and (3) forming automaticity.

Three types of speaking tasks can develop learners' fluency: information-gap tasks, problem-solving tasks and social monologues (Goh, 2007). Information-gap tasks require learners to bridge the gap by exchanging their ideas. Problem-solving tasks request learners to solve problems collaboratively by using English. And social monologues offer learners many opportunities to talk on a given topic. All these three speaking tasks encourage learners to express their opinions freely, so that they can focus on developing their speaking fluency, without distracting their attention to the language form at the same time.

Additionally, Maurice's (1983) 4/3/2 technique is beneficial to gradually develop learners' speaking fluency. First of all, the speaker talks about a topic for 4 minutes; next he repeats the topic within 3 minutes; and then he conducts the same speech within 2 minutes. Obviously, talking about the same topic three times certainly makes learners more familiar with the content; and such increased familiarity reduces learners' anxiety and makes them more fluent in the subsequent performance. This technique is supported by Arevart and Nation (1991), who assert that learners speak quicker with fewer hesitations in the 2-minute talk than the 4-minute talk. Zhou (2006) also states that the $4 / 3 / 2$ technique really enhances Chinese EFL learners' speaking fluency. Therefore, by talking the same topic from 4 minutes to 3 minutes and to 2 minutes, learners' fluency can be gradually enhanced.

Furthermore, as some set phrases and expressions ease students' cognitive stress (Lewis, 1993), free their attention capacity (Skehan, 1996) and speed up their speaking processing (Goh, 2003), Chinese EFL learners need to store large vocabulary in their memory and recall them automatically in speaking. By means of such automaticity, learners reduce the time pressure and cognitive load (McLaughlin \& Heredia, 1996) and thus increase their speaking fluency (Wood, 2001; Wood, 2004; Zhou \& Wang, 2007).

\subsection{Post-Speaking Activities}

Both meaning-focused and form-focused activities should be weighted to develop learners' oral proficiency. Therefore, after the meaning-oriented tasks, learners' accuracy should be emphasized through (1) language-focused activities; (2) self repairs; and (3) corrective feedback.

Language-focused activities improve learners' correct use of language and help them have a better performance in the subsequent similar tasks (Goh, 2007). To improve learners' language accuracy, three stages are carried out: noticing, comparing and integrating (Ellis, 2002). By means of noticing, learners pay attention to certain new characteristics in the target language. Through comparing, learners find out some similarities and differences between their native language and the target language. By integrating, learners transfer those typical features from the target language to their own language use. In this way, it is expected that learners can develop their accurate use of language step by step.

Self repairs also help learners to focus on the correct use of the language form (Lyster \& Ranta, 1997; Gilabert, 2007). It is not sufficient for learners to just use the language; instead, they need to analyze and evaluate their output (Lazaraton, 2001) and correct their own mistakes in the language use (Bygate \& Samuda, 2005). By means of reflecting on their language use, learners develop their oral accuracy (Willis, 1996). For instance, transcribing one's speech enhances learners' correct use of spoken language (Burns, Gollin, \& Joyce, 1997) and help students to achieve "higher rates of accuracy" (Lynch, 2007, p. 311) in terms of pronunciation, grammar and vocabulary.

In addition to self repairs, learners should be helped with "corrective feedback" (Larsen-Freeman, 2001, p. 37). However, if the feedback is given after speaking, some errors may be unnoticed. Therefore, using audiotaped dialogue journals is essential to keep a record of the output (Ho, 2003). By recording their conversations through tapes, students obtain corrective feedback from their instructor (Lazaraton, 2001). The teacher then listens to the tapes one by one and gives responses individually, which is more specific and detailed than commenting generally to the whole class. Besides, learners ask classmates to point out their speaking mistakes. By means of such peer correction, learners can improve their speaking accuracy cooperatively. Corrective feedback from the teacher and/or classmates is very helpful, particularly when learners don't notice their own mistakes in speaking. 


\subsection{Extension Practice}

In order to develop both fluent and accurate spoken language, extension practice needs to be implemented through task repetition. Task repetition is "the repetition of the same or slightly altered tasks whether whole tasks, or parts of a task" (Bygate \& Samuda, 2005, p. 43), which is realized by telling the same topic to different persons, or asking different people about the similar question, or using the same materials to communicate more than once, etc. (Bygate \& Samuda, 2005). Task repetition is by no means pointless; instead, it incorporates what learners have already obtained to what they need to perform. Repeating the task can ease learners' cognitive load (Bygate, 2005) and have "fewer errors" (Bygate, 1996, p. 138) as well as "greater fluency" (Ellis, 2005, p. 18), so task repetition should be applied to Chinese EFL oral classrooms, for it can develop learners' speaking fluency with additional emphasis on accuracy (Bygate, 2001; Lynch \& Maclean, 2001),

\section{Conclusion}

Affected by cognitive, linguistic and affective factors, Chinese EFL learners find it very hard to have both fluent and accurate oral English. Therefore, aiming to enhance Chinese EFL learners' speaking competence, this paper first discusses three effective models of teaching speaking, and then suggests a four-step pedagogical method in Chinese EFL oral lessons, in which activities are carried out through four stages: Pre-speaking; while-speaking; post-speaking; and extension practice. Before speaking, learners should be helped sufficiently in knowledge, vocabulary and strategies so as to reduce their anxiety and pressure. While speaking, learners need to be given time and space to mainly develop their fluency, with full attention to express their meanings. After speaking, learners should be offered chances to notice the correct use of language so as to improve their speaking accuracy. At last, extension practice is significant to reinforce learners' language use, for task repetition helps learners to develop fluent and accurate spoken English. This four-step pedagogical method can be also significant for EFL learners in other countries.

\section{Acknowledgements}

I am sincerely indebted to my supervisor, Dr. Christine C. M. Goh at National Institute of Education, Nanyang Technological University, Singapore, for her valuable guidance and detailed comments and suggestions on the improvement of this paper, and also for her friendly encouragement and kindness during my postgraduate study in Singapore.

\section{References}

Arevart, S., \& Nation, P. (1991). Fluency improvement in a second language. RELC Journal, 22(1), 84-94. http://dx.doi.org/10.1177/003368829102200106

Arnold, J., \& Brown, H. D. (1999). A map of the terrain. In J. Arnold (Ed.), Affect in Language Learning (pp. 1-24). Cambridge: Cambridge University Press.

Brown, H. D. (2001). Teaching by principles: An interactive approach to language pedagogy (2nd ed.). White Plains, NY: Longman.

Brown, H. D. (2007). Principles of language learning and teaching. White Plains, NY: Pearson Longman.

Burns, A., Gollin, S., \& Joyce, H. (1997). Authentic spoken texts in the language classroom. Prospect, 12, 72-86.

Bygate, M. (1996). Effects of task repetition: Appraising the developing language of learners. In J. Willis, \& D. Willis (Eds.), Challenge and Change in Language Teaching (pp. 136-146). Oxford: Heinemann.

Bygate, M. (2001). Speaking. In R. Carter, \& D. Nunan (Eds.), The Cambridge Guide to Teaching English to Speakers of Other Languages (pp. 14-20). Cambridge: Cambridge University Press. http://dx.doi.org/10.1017/CBO9780511667206.003

Bygate, M. (2005). Oral second language abilities as expertise. In K. Johnson (Ed.), Expertise in Second Language Learning and Teaching (pp. 104-127). Baisingstoke: Palgrave MacMillan.

Bygate, M., \& Samuda, V. (2005). Integrating planning through the use of task-repetition. In R. Ellis (Ed.), Planning and Task Performance in a Second Language (pp. 37-74). Amesterdam: John Benjamins Publishing Company.

Carter, R. (2001). Vocabulary. In R. Carter, \& D. Nunan (Eds.), The Cambridge Guide to Teaching English to Speakers of Other Languages (pp. 42-47). Cambridge: Cambridge University Press. http://dx.doi.org/10.1017/CBO9780511667206.007

Ellis, R. (2002). Grammar teaching —Practice or consciousness-raising? In J. C. Richards, \& W. A. Renandya (Eds.), Methodology in Language Teaching: An Anthology of Current Practice (pp. 167-174). Cambridge: 
Cambridge University Press. http://dx.doi.org/10.1017/CBO9780511667190.023

Florez, M. C. (1999). Improving adult English language learners' speaking skills. The CAELA Guide for Adult ESL Trainers, 16-20.

Gilabert, R. (2007). Effects of manipulating task complexity on self-repairs during L2 oral production. IRAL, 45, 215-240.

Goh, C. C. M. (2003). Speech as a psycholinguistic process: The missing link in oral lessons. REACT, 22(1), 31-41.

Goh, C. C. M. (2005). Oracy development in literacy-privileged learning environments: Too little, too late? In J. A. Foley (Ed.), New Dimensions in the Teaching of Oral Communication (pp. 92-110). Singapore: SEAMEO Regional Language Centre.

Goh, C. C. M. (2007). Teaching speaking in the language classroom. Singapore: SEAMEO Regional Language Centre.

Ho, Y. K. (2003). Audiotaped dialogue journals: An alternative form of speaking practice. ELT Journal, 57(3), 269-277. http://dx.doi.org/10.1093/elt/57.3.269

Horwitz, E. K. (2001). Language anxiety and achievement. Annual Review of Applied Linguistics, 21, 112-126. http://dx.doi.org/10.1017/S0267190501000071

Hughes, R. (2002). Teaching and researching speaking. Edinburgh: Pearson Education.

King, J. (2002). Using DVD feature films in the EFL classroom. Computer Assisted Language Learning, 15(5), 509-523. http://dx.doi.org/10.1076/call.15.5.509.13468

Larsen-Freeman, D. (2001). Grammar. In R. Carter, \& D. Nunan (Eds.), The Cambridge Guide to Teaching English to Speakers of Other Languages (pp. 34-41). Cambridge: Cambridge University Press. http://dx.doi.org/10.1017/CBO9780511667206.006

Lazaraton, A. (2001). Teaching oral skills. In M. Celce-Murcia (Ed.), Teaching English as a Second or Foreign Language (3rd ed., pp. 103-115). Boston, USA: Heinle \& Heinle, Thomson Learning Inc.

Levelt, W. J. M. (1989). Speaking: From intention to articulation. Cambridge, MA: MIT Press.

Lewis, M. (1993). The lexical approach: The state of ELT and a way forward. Hove: Language Teaching Publications.

Liu, M. H. (2006). Anxiety in Chinese EFL students at different proficiency levels. System, 34(3), 301-316. http://dx.doi.org/10.1016/j.system.2006.04.004

Lynch, T., \& Maclean, J. (2001). A case of exercising: Effects of immediate task repetition on learners' performance. In M. Bygate, P. Skehan, \& M. Swain (Eds.), Researching Pedagogic Tasks: Second Language Learning, Teaching and Testing (pp. 141-162). Harlow, UK: Person.

Lynch, T. (2007). Learning from the transcripts of an oral communication task. ELT Journal, 61(4), 311-320.

Lyster, R., \& Ranta, L. (1997). Corrective feedback and learner uptake: Negotiation of form in communicative classrooms. Studies in Second Language Acquisition, 19(1), 37-66.

Maurice, K. (1983). The fluency workshop. TESOL Newsletter, 17(4), 29.

McLaughlin, B., \& Heredia, R. (1996). Information-processing approaches to research on second language acquisition and use. In W. C. Ritchie, \& T. K. Bhatia (Eds.), Handbook of Second Language Acquisition (pp. 213-228). San Diego: Academic Press.

Nation, I. S. P. (2001). Learning vocabulary in another language. Cambridge: Cambridge University Press. http://dx.doi.org/10.1017/CBO9781139524759

Saunders, W. M., \& O’Brien. (2006). Oral language. In F. Genesee, K. Lindholm-Leary, W. M. Saunders, \& D. Christian (Eds.), Educating English Language Learners: A Synthesis of Research Evidence (pp. 14-45). Cambridge: Cambridge University Press.

Shumin, K. (2002). Factors to consider: Developing adult EFL students' speaking abilities. In J. C. Richards, \& W. A. Renandya (Eds.), Methodology in Language Teaching: An Anthology of Current Practice (pp. 204-211). Cambridge: Cambridge University Press. http://dx.doi.org/10.1017/CBO9780511667190.028

Skehan, P. (1996). Second language acquisition research and task-based instruction. In J. Willis, \& D. Willis (Eds.), Challenge and Change in Language Teaching (pp. 17-30). Oxford: Heinemann. 
Skehan, P., \& Foster, P. (1999). The influence of task structure and processing conditions on narrative retellings. Language Learning, 49(1), 93-120. http://dx.doi.org/10.1111/1467-9922.00071

Tschirner, E. (2001). Language acquisition in the classroom: The role of digital video. Computer Assisted Language Learning, 14(3/4), 305-319. http://dx.doi.org/10.1076/call.14.3.305.5796

Wang, Q. (2006). A Course in English Language Teaching (2nd ed.). Shanghai: Higher Education Press.

Willis, J., \& Willis, D. (1996). Challenge and Change in Language Teaching. Oxford: Heinemann.

Willis, J. (2005). Introduction: Aims and explorations into tasks and task-based teaching. In C. Edwards, \& J. Willis (Eds.), Teachers Exploring Tasks in English Language Teaching (pp. 1-12). Hampshire: Palgrave Macmillan.

Wood, D. (2001). In search of fluency: What is it and how can we teach it? The Canadian Modern Language Review, 57(4), 573-589. http://dx.doi.org/10.3138/cmlr.57.4.573

Wood, D. (2004). An empirical investigation into the facilitating role of automatized lexical phrases in second language fluency development. Journal of Language and Learning, 2(1), 27-50.

Yuan, F., \& Ellis, R. (2003). The effects of pre-task planning and on-line planning on fluency, complexity and accuracy in L2 monologic oral production. Applied Linguistics, 24(1), 1-27. http://dx.doi.org/10.1093/applin/24.1.1

Zhang, Y. L., \& Jia, G. Z. (2006). Anxiety in foreign language classroom. CELEA Journal, 29(6), 96-103.

Zhou, A. J. (2006). A further study of the effects of the 4/3/2 technique on spoken English production. CELEA Journal, 29(1), 12-20.

Zhou, J. Y., \& Wang, X. F. (2007). Chunking-An effective approach to vocabulary teaching and learning in college classrooms. CELEA Journal, 30(3), 79-84.

\section{Appendices}

\section{Appendix 1}

Questionnaire

Instructions:

The questionnaire aims to find out your experience in English oral communication. Please fill an answer from A.

B. C. to each question according to your first reaction. There is no right or wrong answer. Thank you.

A. Seldom; B. Sometimes; C. Often

1. I___ make mistakes in my pronunciation.

2. I___ make mistakes in grammar when speaking.

3. I___ cannot remember some vocabulary when speaking.

4. I___ speak with pauses and hesitations.

5. I___ use substitution words for those that I do not know.

6. I___ ask for repetition/clarification when communicating with others.

7. I___ worry about making mistakes when talking in English.

8. I am__ misunderstood by my listeners.

9. I___ speak English in class.

10. I speak English out of class.

Appendix 2

Percentage of the speaking problems among junior English majors at CWNU

\begin{tabular}{lccc}
\hline & seldom & sometimes & often \\
\hline Make mistakes in pronunciation & $16 \%$ & $64 \%$ & $20 \%$ \\
Make mistakes in grammar & $9 \%$ & $45 \%$ & $46 \%$ \\
Cannot remember some vocabulary & $4 \%$ & $51 \%$ & $45 \%$ \\
Speak with pauses and hesitations & $6 \%$ & $50 \%$ & $44 \%$ \\
\hline
\end{tabular}




\begin{tabular}{lccc}
\hline Use substitution words for those unknown & $10 \%$ & $38 \%$ & $52 \%$ \\
Ask for repetition/ clarification & $28 \%$ & $65 \%$ & $7 \%$ \\
Worry about making mistakes & $23 \%$ & $44 \%$ & $33 \%$ \\
Misunderstood by listeners & $35 \%$ & $57 \%$ & $8 \%$ \\
Speak English in class & $36 \%$ & $51 \%$ & $13 \%$ \\
Speak English out of class & $58 \%$ & $37 \%$ & $5 \%$ \\
\hline
\end{tabular}

\section{Copyrights}

Copyright for this article is retained by the author(s), with first publication rights granted to the journal.

This is an open-access article distributed under the terms and conditions of the Creative Commons Attribution license (http://creativecommons.org/licenses/by/3.0/). 